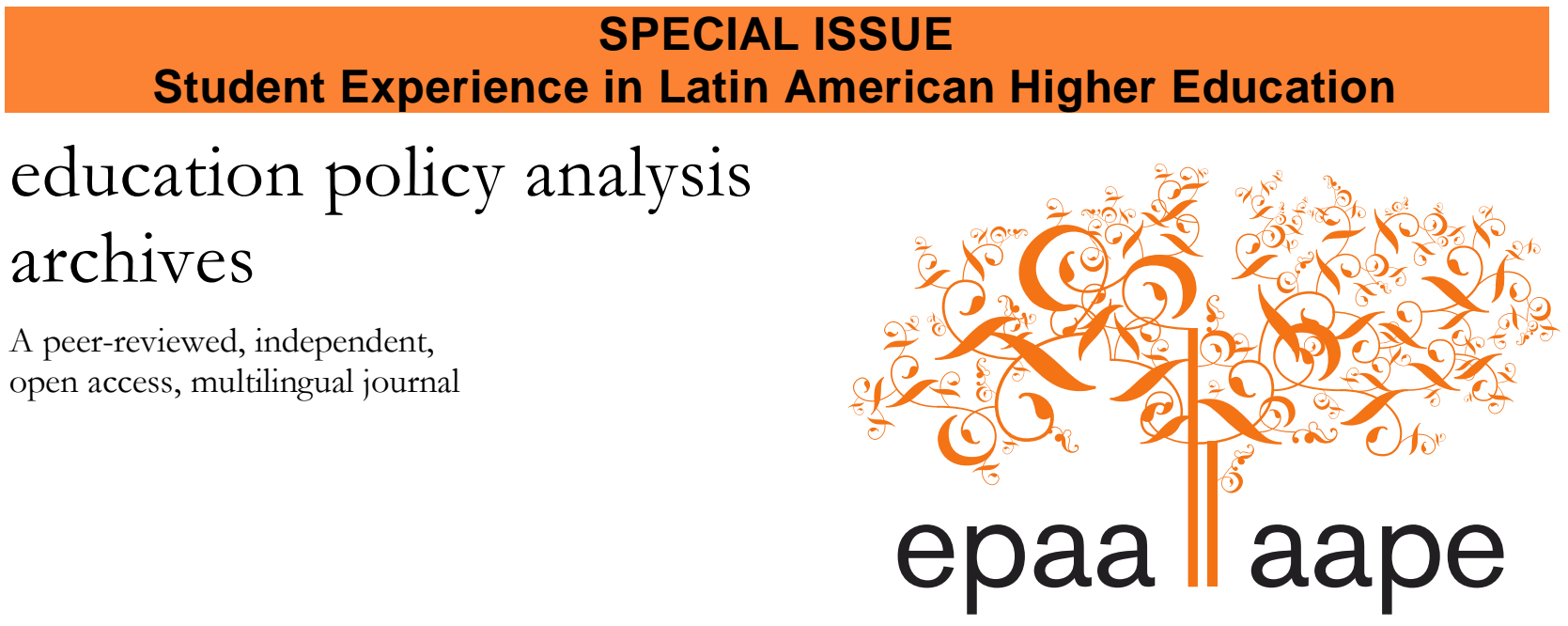

Arizona State University

ISSN 1068-2341

\title{
Resilience in Higher Education: A Conceptual Model and its Empirical Analysis
}

\author{
Samuel de Oliveira Durso \\ Faculdade FIPECAFI \\ Brazil \\ Luís Eduardo Afonso \\ Universidade de São Paulo \\ Brazil \\ \& \\ Susan Beltman \\ Curtin University \\ Australia
}

Citation: Durso, S. de O., Afonso, L. E., \& Beltman, S. (2021). Resilience in higher education: A conceptual model and its empirical analysis. Education Policy Analysis Archives, 29(156).

https://doi.org/10.14507/epaa.29.6054 This article is part of the special issue, Student Experience in Latin American Higher Education, guested edited by Sergio Celis and María Verónica Santelices.

\begin{abstract}
This research analyzes how the resilience of higher education students is shaped during the undergraduate program by personal and contextual factors. In this research, the resilient student is one who faces a high burden of stress and/or adversity during their undergraduate course but manages to reach the end of the program satisfied and/or committed to the chosen career. Based on the literature review, we developed the Academic Resilience Model (ARM), which explains the sources of stress and/or adversity, as well as the protective mechanisms and/or factors that affect students throughout the program. We empirically test this model by conducting a phenomenology-
\end{abstract}


based qualitative study at a public university in Brazil. The results of ARM validation indicate that the main sources of stress and/or adversity and protective mechanisms and/or factors come from individual, academic and external systems. Examples of sources of stress/adversity were the low initial motivation for the program, personal health problems, faculty didactic-pedagogical deficiency, difficulties in relationships with peers, and competing professional demands. On the other hand, the main protective mechanisms/factors identified were the capacity of adaptability, self-control, personal organization, good relationships with the faculty, integration with peers, and support of family. The research enabled identification of how resilience helps students to overcome barriers in higher education, generating important results for future education policies.

Keywords: resilience; retention; higher education; phenomenology

\section{Resiliencia en la educación superior: Un modelo conceptual y su análisis empírico}

Resumen: Esta investigación analiza cómo la resiliencia de los estudiantes de educación superior se configura durante el programa de pregrado por factores personales y contextuales. En esta investigación, el estudiante resiliente es aquel que enfrenta una alta carga de estrés y/o adversidad durante su carrera de pregrado, pero logra llegar al final de los estudios satisfecho y/o comprometido con la carrera elegida. A partir de la revisión de la literatura, desarrollamos el Modelo de Resiliencia Académica (MRA), que explica las fuentes de estrés y/o adversidad, así como los mecanismos de protección y/o factores que afectan a los estudiantes a lo largo del programa. Probamos empíricamente este modelo mediante la realización de un estudio cualitativo basado en la fenomenología en una Universidad Pública de Brasil. Los resultados de la validación MRA indican que las principales fuentes de estrés y/o adversidad y los mecanismos y/o factores de protección provienen de los sistemas individuales, académicos y externos. Ejemplos de fuentes de estrés/adversidad fueron la baja motivación inicial para el programa, los problemas de salud personal, la deficiencia didáctico-pedagógica del profesorado, las dificultades en las relaciones con los compañeros y las demandas profesionales en competencia. Por otro lado, los principales mecanismos/factores protectores identificados fueron la capacidad de adaptabilidad, el autocontrol, la organización personal, las buenas relaciones con el profesorado, la integración con los compañeros y el apoyo de la familia. La investigación permitió identificar cómo la resiliencia ayuda a los estudiantes a superar las barreras en la educación superior, generando resultados importantes para las políticas educativas futuras.

Palabras-clave: resiliencia; retención; educación superior; fenomenología

\section{Resiliência no ensino superior: Um modelo conceitual e sua análise empírica}

Resumo: Esta pesquisa analisa como a resiliência dos estudantes do ensino superior é moldada durante a graduação por fatores pessoais e contextuais. Nesta pesquisa, o discente resiliente é aquele que enfrenta uma grande carga de estresse e/ou adversidade durante o curso de graduação, mas consegue chegar ao final do curso satisfeito e/ou comprometido com a carreira escolhida. Com base na revisão da literatura, foi desenvolvido o Modelo de Resiliência Acadêmica (MRA), que explica as fontes de estresse e/ou adversidade, bem como os mecanismos e/ou fatores de proteção que impactam os estudantes ao longo do programa. O modelo foi empiricamente testado em uma universidade pública brasileira, a partir de um estudo qualitativo de base fenomenológica. Os resultados da validação do MRA indicam que as principais fontes de estresse e/ou adversidade e os mecanismos e/ou fatores de proteção vêm dos sistemas individuais, acadêmicos e externos. Exemplos de fontes de estresse/adversidade foram a baixa motivação inicial para o programa, problemas pessoais de saúde, deficiência didático-pedagógica do corpo docente, dificuldades de relacionamento com os pares e demandas profissionais concorrentes. Por outro lado, os principais mecanismos/fatores de proteção identificados foram a capacidade de adaptabilidade, autocontrole, 
organização pessoal, bom relacionamento com o corpo docente, integração com os pares e apoio à família. A pesquisa possibilitou identificar como a resiliência auxilia os discentes na superação de barreiras no ensino superior, gerando resultados importantes para futuras políticas educacionais.

Palavras-chave: resiliência; retenção; ensino superior; fenomenologia

\section{Resilience in Higher Education: A Conceptual Model and its Empirical Analysis}

Although there is no single definition (Simons et al., 2018), resilience is understood by the American Psychology Association (2014, p.1), as "the process of adapting well in the face of adversity, trauma, tragedy, threats or significant sources of stress — such as family and relationship problems, serious health problems or workplace and financial stressors." Studies on resilience aim to understand why some individuals when subjected to adverse conditions manage to develop satisfactorily and grow, while others, when exposed to these same conditions, may perish, develop pathologies, or see themselves as victims of the situation experienced (Barlach et al., 2008). Therefore, to achieve resilience, there must be a threat to development of some aspect of life and positive adaptation to this adverse situation (Ebersöhn, 2012).

Despite early studies considering resilience as an intrinsic individual trait (Masten, 2015), several authors have argued that this phenomenon is a dynamic state resulting from multiple and complex processes of adaptation, and not a protective shield that is present in all stages of life (Garcia \& Boruchovitch, 2014). Masten (2015) also highlights that, unlike the indication of initial research, resilience is not a rare event that has emerged from the individuals' unique talents and resources but rather a fairly common phenomenon.

In the academic context, the theoretical framework for resilience suggests that individuals exposed to high levels of stress and adversities can avoid school failure by making use of protective mechanisms (personal characteristics) and factors (environmental resource). This generates positive gains, which can be useful for overcoming future adversities in the job market (Brewer et al. 2019; Masten, 2015). Examples of protective mechanisms are positive thinking, personal organization, and problem-solving skills. Examples of protective factors are support of family and friends and the availability of professors (Lessard et al., 2014). On the other hand, when there are no protective mechanisms and factors or when they are not effective and there is a threatening situation, negative adaptation can lead to dropout. Ebersöhn, (2012, p. 33) points out that "These negative outcomes [from a negative adaptation] can be compounded over time to result in, among others, burnout, depression, aggression and withdrawal."

In higher education, the academic environment can be stressful for many students (Robotham, 2008). Examples of situations generating stress include: the change from high school to higher education, which may involve making new friends, moving to another city and leaving the parents' home; pressure to achieve good grades to meet educational demands; financial problems experienced by students and/or their families, which can change living standards; relationship problems within and outside the academic context; imposter syndrome related to study at a highly ranked institution; and possible external demands competing with studies such as work and study at the same time (Hurst et al., 2013, Brewer et al. 2019).

Stress occurs in situations where the homeostasis (organism stability) is threatened (Masten, 2015). The stress itself is not a problem if it is present at a low level (Vasconcellos, 2017). However, a high stress level can negatively affect the progress of studies and lead to dropout. In turn, adversities can be considered those situations that generate risk for an individual (Masten, 2015). The death of parents, for example, can be an adversity for an undergraduate student, as this event changes his/her 
life organization. Sometimes, a high burden of stress also creates a situation of adversity, leading to many types of illness. In this sense, these two constructs (stress and adversity) represent threats to a positive adaptation in higher education (Cox et al., 2016; Wilks \& Spivey, 2010).

For certain groups, the levels of stress and adversity in higher education can be even greater. Some examples are people with no family history of higher education, a significant gap in time between high school completion and entering higher education, those with dependents and/or children, and individuals who study and work full time. All these types are considered non-traditional students in the university context (Cotton et al., 2017). In Brazil, Accounting is an example of a degree with high rates of non-traditional students as it tends to attract individuals already employed, with many holding a degree in other areas and seeking a second degree to complement their knowledge or for a career change (Durso \& Cunha, 2018). The availability of Accounting programs during the evening, enables people to balance academic and professional activities. In 2020, of all Accounting degree programs offered in Brazil, 94\% were delivered in the night period (MEC, 2020). Another factor attracting non-traditional students is that Accounting offers high levels of employment, including for students in early periods of their academic journey (Peleias et al., 2017).

Therefore, our research question is: how is the resilience of higher education students shaped during the undergraduate program by personal and contextual factors? To answer this, we used a phenomenological approach. We developed a theoretical model based on a literature review, which was then empirically tested by interviewing graduating Accounting students in a public Higher Education Institution (HEI) in Brazil. The relevance of this research lies in understanding the important factors that help students overcome challenges faced during higher education program, which can lead to public policies that help promote student satisfaction/commitment with the undergraduate course leading to retention. Furthermore, by proposing and testing a theoretical model that helps explain the process of resilience in tertiary higher education, this research contributes to the scientific development of education. Resilience can be developed in individuals (Masten, 2015), so our results may be useful for establishing institutional programs, which are becoming more common in higher education (Brewer et al., 2019), aiming to provide students with useful protective mechanisms and factors to tackle stress and adversities faced during the course.

\section{Theoretical Model}

Stress can be a positive or negative aspect of human development. Healthy stress is termed 'eustress' and occurs as positive emotions lead to breaking out of homeostasis, which can be understood as the individual's organism stability (Vasconcellos, 2017). However, in elevated rates, stress becomes a threat to people's well-being, leading to an adverse situation, and this stress is known as 'distress' (Masten, 2015). In all stress situations, individuals use defense mechanisms, called coping, and/or protective factors, available in the environments (Ebersöhn, 2012; Vasconcellos, 2017). When mechanisms and/or factors fail to overcome the situation, individuals experience the consequences of stress/adversities and their positive development is threatened. On the other hand, when they work well, the phenomenon of resilience occurs.

\section{Academic Resilience Model}

Figure 1 presents the Academic Resilience Model (ARM), based on resilience theory and the main frameworks that explain retention and dropout processes in higher education (Bean, 1980; Spady, 1970; Tinto, 1975). The model facilitates an understanding of how students in higher education continue their education or dropout from their respective programs. 


\section{Individual System}

The starting point is the individual system, which includes students' family background, personal characteristics, and previous educational experiences. As highlighted in the ARM, while the individual system presents situations of stress and adversity, it can also provide protective mechanisms and factors for the students. For example, an individual who, when starting to study Accounting, does not have a strong desire to finish the program (as their initial aspiration was studying Economics, for instance), may dropout more easily when facing any difficulty related to their academic obligations. On the other hand, those who start their studies effectively aiming to graduate in that specific area will have greater chances of completing the course with satisfaction and commitment to the chosen career (Bean, 1980; Spady, 1970; Tinto, 1975). Ambiel and Barros (2018) highlight the importance of career motivation for students' adjustment to higher education, especially for those who enter immediately after completing high school and who do not have previous experiences to help them in the process of adapting to the new educational context. Thus, the more career oriented the individual is, the less are the chances of dropping out when difficulties related to university context emerge (Bardagi, 2007).

\section{Figure 1}

The Academic Resilience Model (ARM)

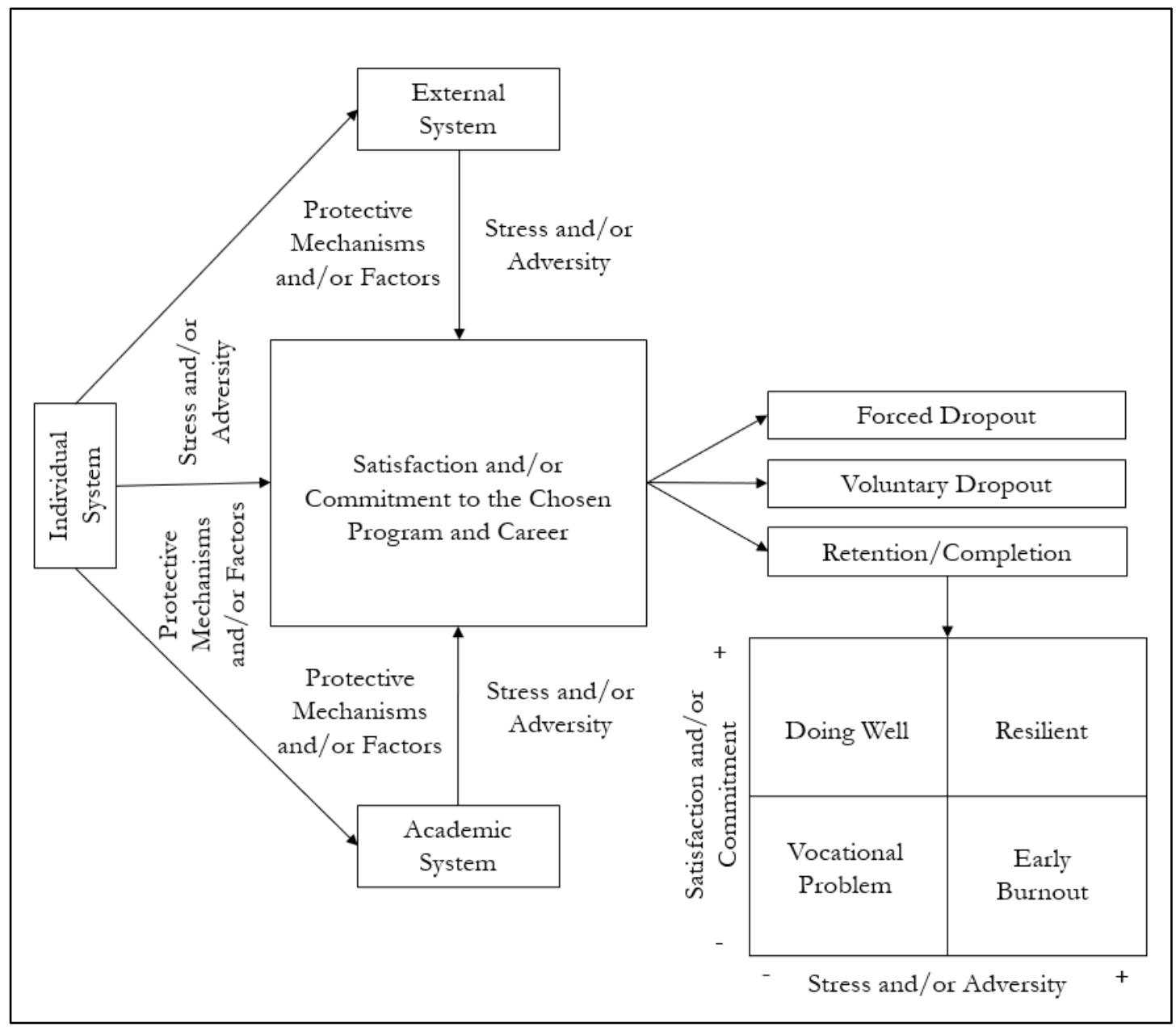

Note: Created by Authors. 
It is important to highlight that in the ARM "satisfaction" and "commitment" are separated constructs. The balance between a student's satisfaction and commitment will bring the likelihood of dropout the course and/or career. The student who has a high level of satisfaction and a high level of commitment will have a lower likelihood of dropout from higher education. However, it is possible for someone who has lower satisfaction, but is highly committed to complete the course and stay in the career to finish the higher education, if this commitment is high enough to sustain this individual until undergraduate completion and beyond. Despite this possibility, it is important to mention that the literature has found evidence of an association between commitment and satisfaction. Highly committed students also tend to show high satisfaction (Chen, 2017).

\section{Academic System}

The academic system can also present protective mechanisms and factors as well as sources of stress and adversity capable of positively or negatively influencing satisfaction and commitment to the academic and professional journey. The first source of protection/threat relates to students' integration with their peers and professors (Spady, 1970; Tinto, 1975). The lack of integration with them can cause social isolation, making studies a more troublesome endeavor. Not bonding during higher education and beyond may lead to psychological and health problems. Difficulties in integration can cause a lack of identification with the academic environment, reduced interest in studying, and reduced satisfaction and commitment to the chosen program and career. On the other hand, individuals who have better integration with peers and professors tend to have more support to face adversities throughout their studies (Wilks \& Spivey, 2010).

Students' backgrounds may also impact the academic system. An individual may have difficulties with integration with their peers when their family, personal and educational background is not compatible with the prevailing conditions in the social environment of the institution. This is common for low-income students who enter an HEI in which most students have higher income (Rubin \& Wright, 2017) or students who enter higher education at an older age (Cotton et al., 2017).

The academic system is crucial for students' academic performance and development, as presented in the models by Tinto (1975) and Spady (1970). In this sense, the evaluation system adopted by the HEI represents one of the most common sources of stress and adversity. Extra class assignments, for instance, can lead to unsatisfactory performance, as students may have difficulties balancing undergraduate studies with professional activities and/or family demands (Cotton et al., 2017). If the HEI uses undergraduate students' academic performance to distribute academic resources (such as scholarship or exchange vacancy), this can increase students' pressure on themselves, resulting in an adverse context due to high level of stress. In all of these cases, students' satisfaction and commitment might be negatively impacted.

The academic system can also be a source of protective factors regarding students' academic performance and development. For example, formal intervention programs aimed at developing students' resilience represent an existing protective factor in the academic environment, which has been increasingly more common in international universities (Brewer et al., 2019).

\section{External System}

The last element impacting on satisfaction and commitment to the chosen degree and career in the ARM is the external system. This includes all environments in which the students interact outside the undergraduate program. Non-academic factors such as sickness, family problems and parallel activities such as work, can affect students' performance in higher education (Cox et al., 2016). For Accounting programs in Brazil, for example, employment represents a strong competing activity for studies as time spent on academic activities is reduced when students must study and work at the same time (Durso \& Cunha, 2018; Hurst et al., 2013). 
Nonetheless, working can also be one of the contributing factors to increase satisfaction and commitment to the degree and career. Brewer et al. (2019) identify uncertainty about entering the job market as one of the main sources of stress for students. So, besides reducing the anxiety about future employment, having contact with the job market can be important for students to see themselves working professionally within the chosen career and an opportunity of using knowledge acquired in the classroom.

\section{Protective Mechanisms and Factors}

When exposed to an adverse condition, individuals can use mechanisms or protective factors to manage the stressful situation at hand (Masten, 2015). According to the ARM, the better the mechanism and/or factor used to overcome the stress and/or adversity situations, the greater the chance for students to complete the program with satisfaction and commitment to the chosen career. In this sense, as shown in Figure 1, the possible outcomes of ARM are: i) forced dropout, when students cannot perform within the levels required by the HEI; ii) voluntary dropout, when the student decides to leave the program, due to low identification with the course, professors or HEI, for example; or iii) retention (till completion), in which the student reaches the end of the program towards graduation. However, not all students who graduate can be considered resilient. Within ARM, positive adaptation, or resilience, is evident when students face high levels of stress and adversity but are still able to maintain good levels of satisfaction and commitment to the chosen program and career.

\section{ARM Outcomes}

For students who reach graduation, there are four possible classifications. These are the four quadrants in the lower rectangle of Figure 1, which consider the level of satisfaction and commitment to the chosen career (axis Y) and the level of stress and adversity faced during the program (axis X). The right upper quadrant representing "Resilient" occurs when the student experiences and successfully overcomes high levels of stress and adversity. This leads to the student reaching the end of the program satisfied and committed to the chosen career. "Doing Well" is represented when a student does not experience high levels of stress and adversity during the program and graduates with satisfaction and commitment to the chosen career (left upper quadrant).

Not every student who experiences high levels of stress and adversity throughout the program and yet manages to graduate can be considered resilient. The third classification (right lower quadrant) is "Early Burnout," when protective mechanisms and factors were not enough to overcome stress and adversity faced during the program. Signs of early burnout have been identified in students in the final periods of their undergraduate program, especially in Accounting area (Peleias et al., 2017; Smith et al., 2020). Finally, when a student experiences low levels of stress and adversity, but still reaches graduation with low satisfaction and commitment to the chosen career, we have the fourth classification (left lower quadrant), called "Vocational Problem". In this case, the student reached graduation with low satisfaction and commitment not due to any problems occurring during the program but due to the individual issues that caused low identification with the chosen career.

It is important to mention that our model can be applied to different scenarios. During the pandemic context of Covid-19, for example, many new adversities and stress situations may have impacted students' lives. Individuals who need more social contact may have perceived more sources of stress/adversity in the individual system of ARM due to social isolation. The academic system, on the other hand, may have changed by the introduction of new Technologies of Information and Communication (TIC), which students may not be familiar with, increasing the load of stress/adversities in the learning process. To the external system, the death of family members or loved ones probably also has impacted many students. 


\section{Methodology}

\section{Phenomenology}

This research aims to analyze how the resilience of higher education students is shaped during the undergraduate program by personal and contextual factors. Completing an undergraduate program is a complex process involving several factors that can affect students' decisions to continue or dropout, as illustrated in the ARM. Because this research is focused on studying a human phenomenon of resilience in a higher education setting, the chosen philosophical paradigm is interpretivism, comprising many types of methods aiming to understand the social world (Smith et al., 2009). One methodology aligned with an interpretivist paradigm used extensively is phenomenology (Grace \& Ajjawi, 2010), where studies focus on issues involving, for example, perception, emotion, self-awareness, personal identity, awareness of others and practical and social activities (Smith et al., 2009).

\section{Setting}

To achieve the proposed objective, interviews were conducted with final year Accounting students at one of the main HEIs in Brazil. The study was approved by the university's Research Ethics Commission. This university is exceptionally large and ranked highly in research between HEI in Latin American. It is publicly funded so students do not pay tuition fees. There is a high demand for places in all courses, including Accountancy, and students undergo a rigorous selection process.

\section{Data Collection and Participants}

Semi-structured interviews were chosen because they enable students to interpret their experiences during the undergraduate program. Before interviews were carried out with the study participants, two pre-tests were performed with Accounting students from another HEI in order to validate the script built for the research. Before selecting the participants, a questionnaire was used to collect initial information about possible levels of stress and adversity experienced during the course, the level of satisfaction and commitment to working professionally in the Accounting area, and socioeconomic information about Accounting students. The last question of this questionnaire asked if individuals would be willing to participate in an interview. The strategy to access the research target audience through a previous instrument has been successfully used before (Simons et al., 2018) and enables the triangulation of data, which is an important element for phenomenological research (Arksey \& Knight, 1999).

Participants were in the final year of the Accounting program as this group is closer to graduation, so they had already lived this experience. They were the appropriate group to inform us about the stress and/or adversity they needed to face (and how they did this) during undergraduate period. In this sense, this study uses a purposeful sampling to answer the research question. Of 138 students completing the questionnaire, 58 expressed interest in being interviewed. Twenty-five responded to invitations (13 women and 12 men) and were interviewed in person between 2018/2 and 2019/1. Figure 2 presents an overview of the data collection process.

\section{Interview Questions}

The script for the semi-structured interviews was based on previous studies that applied a qualitative research methodology (Ebersöhn, 2012, Lessard et al., 2014; Morales, 2008; Theron \& Theron, 2014), and on the framework of the theoretical model developed by the research (the ARM). The interview script covered questions regarding the five dimensions related to resilience, which were addressed over four macrocontexts: i) life before the Accounting program; ii) the decision to study the Accounting degree; iii) life after entering the Accounting program; and iv) plans for the 
future. In the third macrocontext, two activities were conducted, with two objectives. The first was to collect data from another source so that it is possible to understand the phenomenon under investigation from different angles. This process assists researchers in triangulating data (Arksey \& Knight, 1999). The second objective was to bring dynamism to in-depth interviews (that have long duration), introducing breaks that make data collection less boring for participants.

\section{Figure 2}

Summary of Data Collection Process

\section{Data Collection Summary}

Applying the Questionnaire

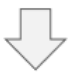

Aiming for participant selection for the interview stage, gathering primary information about stress and adversity experienced by students as well as level of satisfaction and commitment to the chosen career for the triangulation process

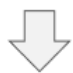

138 participants answered the questionnaire

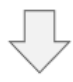

58 respondents were interested in participating in the interview stage
Carrying out the Interview

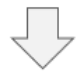

Aiming to collect information that would allow us to understand how the how higher education students' resilience is shaped by personal and contextual factors

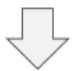

Out of the 58 respondents willing to be interviewed, 25 accepted the invitation

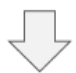

There were two activities carried out to go more in depth the topic being addressed and also help in the triangulation process

In the first activity, a graph was presented in which the Y-axis represented the student's current satisfaction and commitment to the Accounting profession (in its most diverse spheres). The $\mathrm{X}$-axis represented the levels of stress and adversity the student experienced during the entire Accounting program, by factors whether internal or external to HEI (in accumulative way). The student was asked to mark a point that represented him/her in the graph. This first activity made it possible to verify each participant's self-perception about the level of stress and adversity experienced throughout the program and, also, the self-perception of satisfaction and commitment to the career in Accounting, making it possible to classify each participant according to the four categories of ARM: i) doing well; ii) resilient; iii) early burnout; or iv) vocational problems.

The second activity presented a list of possible resources pointed out by the literature as relevant for the occurrence of resilience in several contexts. Participants should divide these resources into two groups (important versus non-important), based on their history during their undergraduate program in Accounting. In addition to making it possible to identify important resources in the student's own perspective for overcoming the stress and adversity experienced throughout the program, this activity served for students to reflect on the resources that were important for overcoming the stress and adversity experienced, aligning with a phenomenological approach (Smith et al., 2009). 


\section{Data Analysis}

The literature describes three important methods to analyze data from phenomenological studies (Grace \& Ajjawi, 2010; Smith, 2006). The first is "bracketing" and represents the process by which the researcher leaves aside personal assumptions and focuses only on participants' experiences (Smith, 2006). The second method is "interpretation", which consists of attributing meaning to the daily context after subjects reflect on the phenomenon. "Analysis" is the last method and uses a logical approach to understand the data collected in phenomenological studies, when researchers reflect on a repertoire of common experiences presented by participants.

Interviews took about one hour and on average each interview yielded 32 pages of transcription, encoded using NVivo ${ }^{\circledR}$ software. Data from the interviews were also triangulated with the responses obtained for the same individuals via questionnaire (sample selection strategy), enabling greater robustness for the results achieved by the investigation. The interviews achieved the completeness and data-saturation criteria of the information collected, according to the practices usually performed in qualitative approaches that use semi-structured interviews (Morales, 2008). To ensure the anonymity and confidentiality of participants, codes are used in the presentation of results.

\section{Results and Discussion}

Figure 3 presents the ARM, contextualized with the main research findings from the 25 participants' interviews and questionnaires. For each of the three systems affecting students' satisfaction and commitment to the Accounting program and career, factors leading to stress and adversity, and protective mechanisms and factors are presented.

\section{Individual System: Stress and Adversity}

The first impact on students' satisfaction and commitment to the program and career in Accounting comes from their own background, represented by the individual system. One of the main factors that threatens the continuity of students relates to low initial motivation regarding the program and a career in Accounting. Most participants did not intend to join the Accounting program when they applied to join the institution. Out of the 138 questionnaires answered in the first stage of data collection, only $52(38 \%)$ indicated having chosen Accounting as their first option. For the 25 interviewed, this percentage was 36\%. Many students interviewed did not know what the area of training in Accounting was about when they joined the HEI.

The HEI allows four career options in the business area with each offered in the daytime or evening. For example, a student who chooses Economics Daytime as the first option and Accounting Daytime as the second option may not score enough to be admitted to the first option but may manage to be admitted to the second option. Competition for Accounting course is lower than others and, after the first year, the HEI allows for the change in the program. Several participants highlighted that they knew that after the first year it would be possible to request a change to their first option depending on the availability of vacancies and the student's performance during the first year. This is evident in participant E22's interview:

I chose Economics Daytime, Economics Nighttime [...] then Administration, I think Daytime; and Accounting Daytime. And then I got in into Accounting [...] I thought: "No! I do it for a year, and then I switch to Economics." (E22)

Although there is some similarity between business careers in Brazil, the work done in each area differs greatly. Thus, starting a program for which there is no strong motivation represents a factor of stress and adversity as the chance of dropping out increases (Bardagi, 2007) or the student may reach the end of the course with no motivation to work in the area studied. 


\section{Figure 3}

Academic Resilience Model (ARM) with Research Results

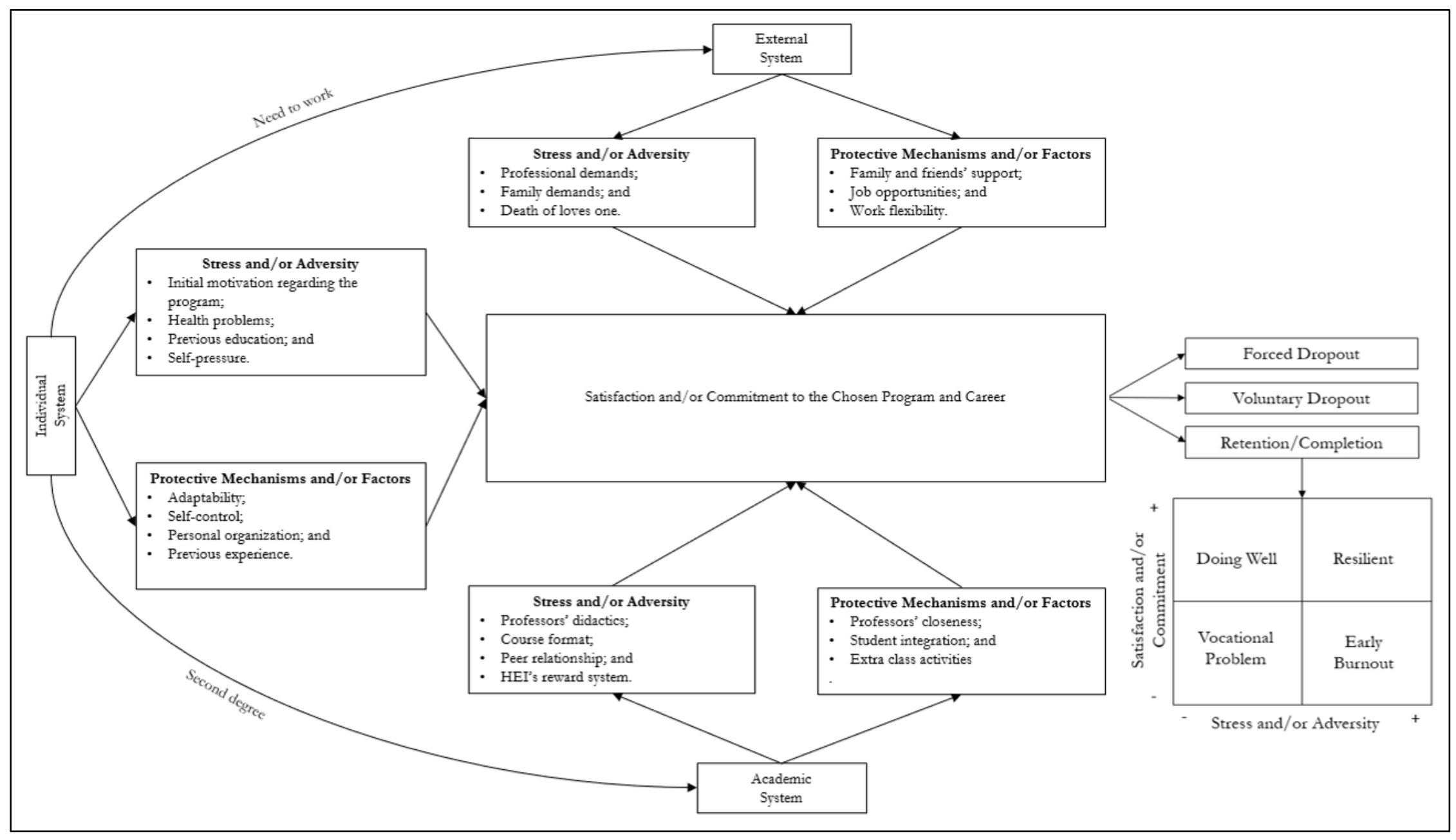


Another individual system source of stress and adversity was that some participants experienced health problems during the course, which can hinder performance and, ultimately, lead to dropout, either voluntarily or by unsatisfactory performance. Research by Cox et al. (2016) highlights that events external to academic life, such as illness, can significantly impact the condition of the student in higher education. The evidence collected in the interviews is supported by the theoretical models of resilience built from a socioecological perspective, which consider the various layers of life as likely to bring risk and adversity, as well as resources, to the individual in different contexts $(\mathrm{Gu}, 2018)$.

The third most important individual system source of stress and adversity for Accounting students, was their previous education. Many students who enter the Accounting program have initial education in another, sometimes entirely different area. In the 138 questionnaires, 29 (21\%) students had already completed a first degree. Among the 25 interviewees, 11 (44\%) were in this situation. The change in area and paradigm of thinking proved challenging for some participants, increasing the levels of stress experienced throughout the program, especially in the initial periods. First-time undergraduate students who had inadequate basic training, especially in the quantitative area also experienced challenges adapting to higher education. To thrive in the program, these individuals needed more dedication than their peers whose educational background was more favorable. These findings are in line with the main theories on higher education dropout (Spady, 1970; Tinto, 1975) which highlight academic aspects preceding the program as important for students' retention.

The final source of stress and adversity in the individual system was the pressure students put on themselves. Some participants showed signs of self-pressure for high academic performance, either to achieve external rewards or by internal motivation. The need for high performance can increase the levels of stress, made even worse in this HEI environment which has a very demanding admission process. E1's interview highlights self-pressure and lack of knowledge about higher education at the beginning of the program:

[...] in the beginning, I was apprehensive about scores, the grades, and everything else. So, that, I think most of the stress is there [...] I worried a lot because not knowing what would be the level of demand by the professors... every semester we have different professors. (E1)

One of the main difficulties in higher education for students relates to academic demands in the program (Brewer et al., 2019). Seeking, but not achieving, high standards of performance can cause the student to develop other problems such as anxiety, depression, feeling powerless and incapable, and develop imposter syndrome (Hurst et al., 2013).

\section{Individual System: Protective Mechanisms and Factors}

In the individual system, as defined by the ARM, despite being a source of stress and adversity, the individual's background also provides protective mechanisms and factors. Throughout the interviews, there were several situations when participants made use of personal mechanisms such as adaptability, self-control and personal organization, that are important personal resources for the resilience process (Masten, 2015). Moreover, for students who entered the Accounting program having already graduated in another area, previous experience with the processes and demands in higher education proved to be relevant for facing (or minimizing) difficulties. This was present for E24, who graduated in journalism and performing arts before starting Accounting: 
So, I was familiar with it [refers to the functioning of higher education], because I had already come from other degrees, I was familiar with it; so, for me it was ... I already had, at least, an understanding. (E24)

\section{Academic System: Stress and Adversity}

The second system presented by the ARM is the academic environment. One of the main sources of stress and adversity for students of Accounting concerns the didactic-pedagogical strategies used by professors, mainly in quantitative courses (such as Applied Calculus and Business Calculus), which appeared in the responses of all participants. The interaction and availability of professors during and after classes and the support material used in these courses were types of didactic-pedagogical dissatisfaction that generated several stressful situations for students. In the main models of student retention in higher education (Spady, 1970; Tinto,1975), identification and good relationships with the faculty appear as fundamental structures to avoid student dropout. The relationship with professors, however, can also represent a source of stress and adversity if the relationship established is negative.

In relation to course format, an interesting result was the dissatisfaction of participants with the courses taught in Finance using distance learning strategies which did not meet their needs and expectations, since they were enrolled in a face to face undergraduate course. A similar result was found in the US where participants, mostly non-traditional students from Colleges offering face-toface programs, considered that online classes did not provide the necessary support to achieve a good performance (Jaggars, 2014).

Difficult relationships with peers were a source of stress, mainly due to the heterogeneous environment in the Accounting program. Although interviewees reported that they were able to create affective bonds with other students throughout their program, differences in age, professional experiences and socioeconomic conditions created distance among some students. This is clear from the E11 who already had a first degree, and entered the Accounting Daytime program marked by the presence of younger students:

Everyone was 18 years old... everybody had the car key in their hands, I said: "Guys, this is way out of reality"... basically everybody was white... everybody white, with an iPhone [...] Everyone had already been abroad at 18; I only traveled abroad at 21, 22; because I worked for it, [...] I saved money and traveled. (E11)

Difficulties in integration were greater for students already employed when starting Accounting. Less time was available for extracurricular activities and the university life experience, leading to difficulties with rapport. This is in line with the findings of Rubin and Wright (2017) that highlight the difficulty of academic social integration for students classified as working-class, who tend to be older and more likely to have professional and family demands. Integration among students is one of the pillars in the main models of student retention in higher education (Spady, 1970; Tinto, 1975). The less integrated the student is with their peers, the greater the chance of dropping out (voluntarily or not).

Finally, another important source of stress and adversity concerns this university's reward system, which relates to grades obtained throughout the program. The weighted average is used, for example, for choosing electives, and for allocating scholarships for academic exchange. For some students, the reward system appears unfair and has a direct impact on education. In the words of E5:

Well, there are so many electives that I had to do, nothing to do with the program,

because the electives are also assigned by weighted average; and, many times, you can't get the course in your area, because all spots are taken; so, I had to do, like, 
Design, in the Faculty of Architecture, you know? What will Design contribute [...] to what I want for life? (E5)

\section{Academic System: Protective Mechanisms and Factors}

One of the main protective mechanisms and factors of the academic environment is the academic support of professors, as it allows more flexibility for the course work and carrying out evaluation activities. The more available the professor was to students (in class and extra class), the more the students perceived the professor as a support in the educational process. The practice of studying and working at the same time is common for Accounting programs in Brazil (Durso \& Cunha, 2018; Peleias et al., 2017). Out of the 138 respondents from the questionnaire stage, 64 $(46 \%)$ said they had worked and studied simultaneously for more than four semesters (i.e., more than half of the program). Among those interviewed, this percentage was $60 \%$. In order to balance the various demands (studying, work and personal life) the professors' flexibility (regarding attendance and due dates for activities, for example) proved to be important for the respondents to reach the end of the program. From a resilience perspective, the relationship with the faculty is also important for overcoming adversities (Lessard et al., 2014).

Integration with other students was also important to ensure the sense of belonging necessary for academic development. The extracurricular activities (such as junior companies, collectives, and support groups) that exist at the HEI were mentioned by several students, especially those who joined right after high school, as relevant for the formation of affective bonds with other students. Research on resilience in higher education highlights the role of peer support as important in overcoming difficulties that appear throughout the program (Hurst et al., 2013; Wilks \& Spivey, 2010).

\section{External System: Stress and Adversity}

External environments to the program also directly or indirectly affected students' satisfaction and commitment to the chosen program and career. One of the main challenges of external environments were professional demands. Some entered the program already working while others started working at the beginning of the program. Even for students in the second group, professional demands can directly impact their academic development. Interviewee E18, who entered the Accounting program right after finishing high school said that he went to hospital due to work stress:

[...] in this transition from intern to employee, it was because of my performance[...], and that one person left too, and then a new position came up. This person just quit, like, overnight, almost; [...] then, it was a very quick period that she passed this information on to me [...] after she left, I was kind of lost; [...] just an example, I felt my eyelid trembling, like this; I felt my heart racing when I was at work; then, I felt that I was ill. Then this one day [...] during lunchtime, I felt my heart pounding... I was a hyperventilating, and I was kind of limp, kind of weak, I decided to go to the hospital, I had IV saline... Yeah, I went through a stress crisis. (E18)

In addition to the pressure of work responsibility, long hours of work, difficulties moving between home-work-university, harassment and the stress of changing jobs were situations that negatively impacted some of the 25 respondents. Attempting to study and work at the same time can be challenging for students, including those with part-time jobs (Mounsey et al., 2013). Having a job as a competitor to studying may increase the stress perceived by individuals during the program, 
making it difficult to graduate, or causing the individual to reach the end of program with low satisfaction and commitment to the chosen career.

Family demands also represented a source of stress and adversity. Because the course attracts non-traditional students who are sometimes older, issues related to adult life, such as weddings, divorce and children getting sick, occurred throughout the program. Some cited the death of family members as a source of stress and adversity that needed to be faced during the program. Among the cases analyzed, the death of grandparents (four cases) was the most common, but the death of father (one case) and mother (one case) were also reported. Cox et al. (2016) highlights the death of family members or close friends as a factor influencing the likelihood of students not completing the program, in the US context. Death can change some perspectives in the student's life, altering their commitment to the HEI and/or to graduating, fundamental factors for the student's permanence in higher education (Spady, 1970; Tinto, 1975).

\section{External System: Protective Mechanisms and Factors}

Regarding protective resources from the external environment, the support of family members (financially or otherwise) proved to be important for students to be able to continue in their program, as expected by the literature (Masten, 2015). The participant E14, for example, who already started the Accounting program as a father, pointed out the importance of his wife in balancing academic and personal demands:

$[\ldots]$ for example, when an exam is coming up and one of my children gets sick; so, my wife takes full responsibility for them. [E14]

A second relevant factor was the job opportunities existing in the Accounting market. This source, which appeared as an important motivational factor for several groups of participants, proved to be even stronger for those already graduated who were looking for a change in their area of expertise, which is a common phenomenon in undergraduate Accounting in Brazil (Durso \& Cunha, 2018). By considering the possibilities of working in the Accounting area and having found employment opportunities in the area in the initial periods of the program, these students were able to maintain a good level of satisfaction and commitment to the program and career throughout their studies. Finally, the third protective factor of the external system concerns the flexibility existing in the individual's work environment. This was the case of the participant E12, a woman who completed her higher education in Law before starting to study Accounting and worked as a consultant in an office during her second degree:

$[\ldots]$ I am fortunate to work in a place that is extremely flexible with me, regarding to schedules. For example, today, I did home-office, I spent half the day dedicating to my office demand and the other half, I spent writing my project [refers to the undergraduate dissertation]. [E12]

For some participants, especially for those who entered the Accounting program already employed, having an occupation that presented flexibility of schedules and that understood the academic needs of individuals proved to be fundamental to balance the multiple demands that students had to fulfill.

\section{ARM Outcomes}

As proposed in the ARM, situations of stress and adversity when confronted with protective mechanisms and factors can result in three possible outcomes: i) forced dropout, ii) voluntary dropout or iii) retention until completion. As the purpose of this research was to analyze how the resilience of higher education students is shaped throughout the program by personal and contextual factors, the possible outputs of dropout on ARM have not been investigated. In this sense, this 
research empirically tested the resilience process of students who were enrolled in the last year of the Accounting program, that is, who were close to graduating. Not all near-graduating members, however, can be classified as resilient according to the ARM. Figure 4 presents the results of the first graphing of stress and satisfaction activity during the interview.

Participants did not have access to the ratings in Figure 4. Only the axes related to levels of stress and adversity experienced along the program (X-axis) and the current satisfaction and commitment to the career (Y-axis) were presented. "Vocational problem" and "early burnout" obtained one occurrence (4\%) each. For these groups, a lower frequency was expected, as vocational problems or burnout signs can more likely lead to dropping out before completion (Bardagi, 2007; Smith et al., 2020). Since the study sample included students who were in the last year of undergraduate program, most dropout cases, likely, had already occurred.

\section{Figure 4}

Participants' Self-Classification

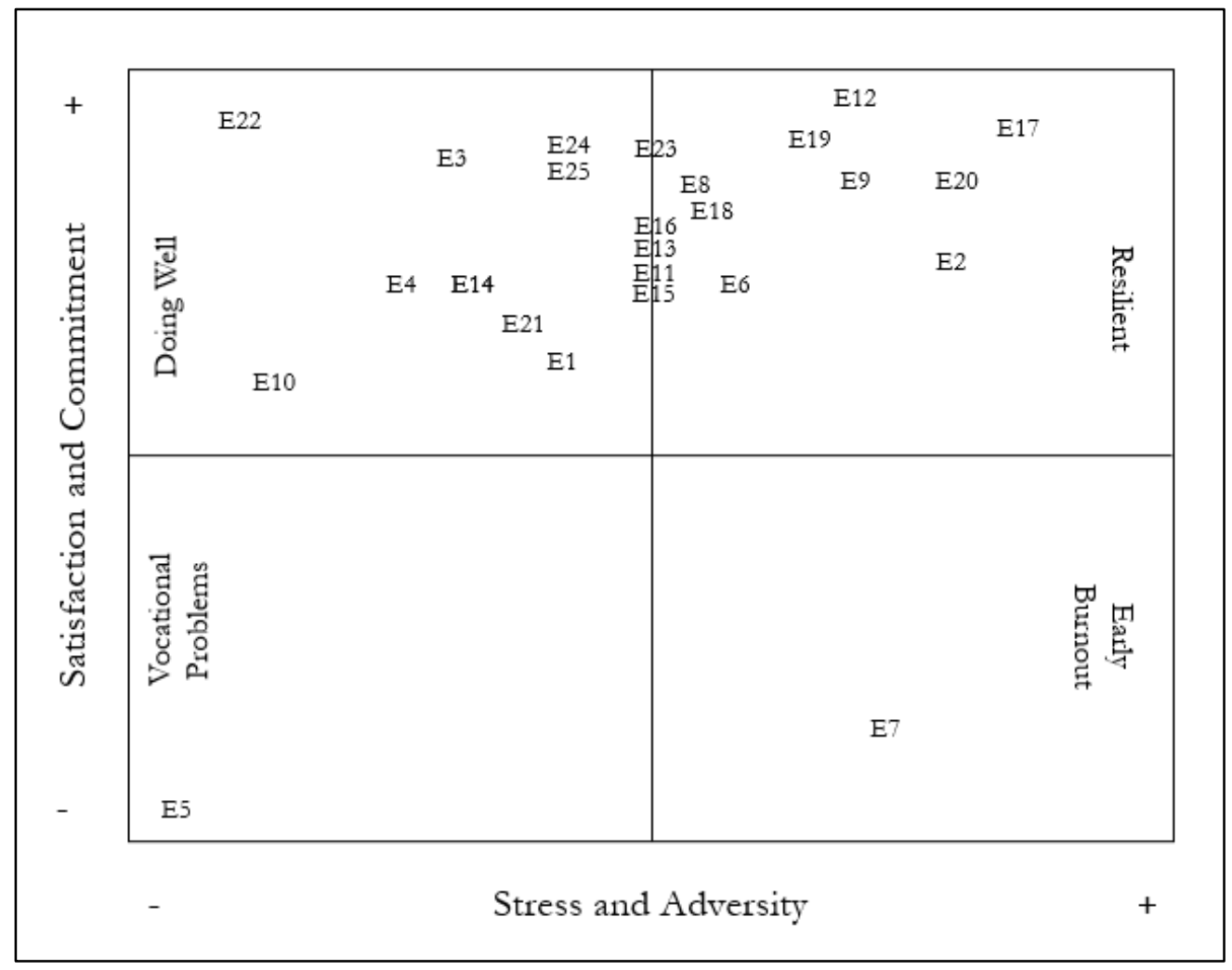

Of the 25 participants, $9(36 \%)$ were self-classified as "doing well". For this group, the levels of stress and adversity were not significant (in the chart, $<50 \%$ ) and the satisfaction and commitment to the career are at appropriate levels ( $\geq 50 \%)$. In the "resilient" quadrant, 14 (56\%) students self-classified indicating having experienced high levels of stress and adversity $(\geq 50 \%)$ but, even so, showed significant levels of satisfaction and commitment to the career. It is important to highlight that resilience is an individual phenomenon (Masten, 2015). In this sense, although we can identify some patterns, the resilience process is unique, since the stress/adversity situations and protective mechanisms/factors can vary from student to student throughout higher education. 


\section{Conclusion}

The objective of this research was to analyze how the resilience of higher education students is shaped throughout the program by personal and contextual factors. Based on the theoretical model developed and its empirical analysis, it was possible to identify, with a phenomenological approach, that factors that cause stress and adversity are common during the undergraduate program, which can impact course satisfaction and commitment to the career. For resilience to occur, students need to use protective mechanisms (related to the individuals) and/or protective factors (from the surrounding environments) to overcome these challenges.

Results indicate that both stress and adverse situations and protective mechanisms and factors come from the same sources: i) individual system, ii) academic system and iii) external system. For the case studied here (Accounting program at an important Brazilian HEI), factors such as low initial motivation to enter the program, health problems, deficiency in previous education and excessive self-pressure were the main sources of stress and adversity arising from the individual system. The main protective mechanisms related to the individual were adaptability, self-control, personal organization, and previous educational experiences.

For the academic context, the main sources of stress and adversity were related to didacticpedagogical issues, relationships with peers and the HEI reward system based on students' academic performance. Protective factors related to the academic system, were the relationship with the faculty, integration with peers and the possibility of extracurricular activities. For the external system, the main sources of stress and adversity were the competing demands (professional and family) and the death of loved ones. Protective factors related to the external context were the support of family and friends, the opportunity of employment in the area of activity and, for those already employed, the flexibility of work.

Regarding the limitations of the research, it is necessary to emphasize that qualitative phenomenological investigations, as in the case of the present study, do not allow empirical generalizability of the findings for other contexts, but theoretical transferability (Smith et al., 2009). As resilience is a unique phenomenon, resulting from the process of exchange between the individual and the environment in which he/she is situated, it is not feasible to define a single possibility for the phenomenon. Nevertheless, by proposing and testing a model that integrates the theory of resilience with the theory of retention in higher education, the results of this study contribute to the theoretical understanding of the phenomenon addressed.

The results of this investigation can be useful for the advancement of the literature in the area, as it helps to understand, from a resilience perspective, how the process of dropout or completion of an undergraduate program occurs. However, future research may complement our findings. The application of ARM to different contexts and undergraduate programs can help to better understand the role of academic resilience in higher education. Considering the possibilities of our model, it may be important to compare the stress and adversity faced by dropout and resilient students, as well as the protective mechanisms and factors they used throughout the course. Longitudinal studies may be useful to deeply understand these issues.

Moreover, by analyzing how the resilience of students in higher education is shaped by personal and contextual factors throughout the program, it has been possible to identify patterns that may be useful in creating educational policies and programs for students in various areas that aim to strengthen and/or develop resilience in students, which may represent an important strategy to prevent dropout in higher education. The literature has shown that interventions can develop the individual's resilience (Masten, 2015). We may not anticipate all students who will face a significant 
burden of stress and adversity, but by implementing strategies to develop their protective mechanisms and factors we may make higher education more inclusive.

\section{References}

Ambiel, R. A. M., \& Barros, L. O. (2018). Relação entre evasão, satisfação com escolha profissional, renda e adaptação de universitários. Psicologia: Teoria e Prática, 20(2), 254-267. http://dx.doi.org/10.5935/1980-6906/psicologia.v20n2p254-267

American Psychological Association - APA. (2014). The road to resilience. http://www.apa.org/helpcenter/road-resilience.aspx

Arksey, H., \& Knight, P. (1999). Interviewing for social scientists. SAGE.

Barlach, L., Limongi-França, A. C., \& Malvezzi, S. (2008). O conceito de resiliência aplicado ao trabalho nas organizações. Interamerican Journal of Psychology, 42(1), 101-112. http://pepsic.bvsalud.org/scielo.php?pid=S0034-96902008000100011\&script=sci_abstract

Bardagi, M. P. (2007). Evasão e comportamento vocacional de universitários: Estudo sobre o desenvolvimento de carreiras na graduação. (Dissertation). Programa de Pós-graduação em Psicologia, Universidade Federal do Rio Grande do Sul. Porto Alegre, Rio Grande do Sul, Brasil. https://lume.ufrgs.br/bitstream/handle/10183/10762/000602010.pdf?sequence=1\&isAllowe $\mathrm{d}=\mathrm{y}$

Bean, J. P. (1980). Dropout and turnover: The synthesis and test of casual model of student attrition. Research in Higher Education, 12, 155-187. https://doi.org/10.1007/BF00976194

Brewer, M., van Kessel, G., Sanderson, B., Naumann, F., Lane, M., Reubenson, A., \& Carter, A. (2019). Resilience in higher education students: A scoping review. Higher Education Research and Development, 38(6), 1105-1120. https://doi.org/10.1080/07294360.2019.1626810

Chen, Y. C. (2017). The relationship between brand association, trust, commitment, and satisfaction of higher education institutions. International Journal of Educational Management, 31(7), 973-985. https://doi.org/10.1108/IJEM-10-2016-0212

Cotton, D. R. E., Nash, T., \& Kneale, P. (2017). Supporting the retention of non-traditional students in higher education using resilience framework. European Educational Research Journal, 16(1), 6279. https://doi.org/10.1177/1474904116652629

Cox, B. E., Reason, R. D., Nix, S., \& Gillman, M. (2016). Life happens (outside of college): Noncollege life-events and students' likelihood of graduation. Research in Higher Education, 57(7), 823-844. https://doi.org/10.1007/s11162-016-9409-z

Durso, S. O., \& Cunha, J. V. A. (2018). Determinant factors for undergraduate student's dropout in an accounting studies department of a Brazilian public university. Educação em Revista, 34(e186332), 1-28. http://dx.doi.org/10.1590/0102-4698186332

Ebersöhn, L. (2012). Adding 'flock' to 'fight and flight': A honeycomb of resilience where supply of relationships meets demand for support. Journal of Psychology in Africa, 22(1), 29-42. https://doi.org/10.1080/14330237.2012.10874518

Garcia, N. R., \& Boruchovitch, E. (2014). Casual attributions for school performance and resilience of students. Psico-USF, 19(2), 277-286. https://doi.org/10.1590/1413-82712014019002003

Grace, S., \& Ajjawi, R. (2010). Phenomenological research. In J. Higgis, N. Cherry, R. Mackling, \& R. Ajjawi (Eds.), Researching practice: A discourse on qualitative methodologies (Vol. 2, pp. 197-208). Sense Publisher.

$\mathrm{Gu}, \mathrm{Q}$. (2018). (Re)conceptualising teacher resilience: A social-ecological approach to understanding teachers' professional worlds. In M. Wosnitza, F. Peixoto, S. Beltman, \& C. F. Mansfield (Eds.). Resilience in education: Concepts, contexts and connections (Vol, 1, chap. 2, pp. 13-34). Springer. https://doi.org/10.1007/978-3-319-76690-4_2 
Hurst, C. S., Baranik, L. E., \& Daniel, F. (2013). College student stressors: A review of the qualitative research. Stress \& Health, 29(4), 275-285. https://doi.org/10.1002/smi.2465

Jaggars, S. S. (2014). Choosing between online and face-to-face courses: Community college student voices. American Journal of Distance Education, 28(1), 27-38. https://doi.org/10.1080/08923647.2014.867697

Lessard, A., Fortin, L., Butler-Kisber, L., \& Marcotte, D. (2014). Analyzing the discourse of dropouts and resilient students. The Journal of Educational Research, 107(2), 103-110. https://doi.org/10.1080/00220671.2012.753857

Masten, A. S. (2015). Ordinary magic: Resilience in development. Guilford.

Ministério da Educação - MEC. (2020). Cadastro Nacional de Cursos e Instituições de Educação Superior. https://emec.mec.gov.br/

Morales, E. E. (2008). Exceptional female students of color: Academic resilience and gender in higher education. Innovative Higher Education, 33, 197-213. https://doi.org/10.1007/s10755008-9075-y

Mounsey, R., Vandehey, M., \& Diekhoff, G. (2013). Working and non-working university students: Anxiety, depression, and grade point average. College Student Journal, 47(2), 379-389. https://www.ingentaconnect.com/content/prin/csj/2013/00000047/00000002/art00014

Peleias, I. R., Guimarães, E. R., Chan, B. L., \& Carlotto, M. S. (2017). The burnout syndrome in accountancy students from Private HEI: A research in the city of São Paulo. REPeC, 11(1), 31-52. http://dx.doi.org/10.17524/repec.v11i1.1468

Robotham, D. (2008). Stress among higher education students: Towards a research agenda. Higher Education, 56(6), 735-746. https://www.jstor.org/stable/40269100?seq=1\#page_scan_tab_contents

Rubin, M., \& Wright, C. L. (2017). Time and money explain social class differences in students' social integration at university. Studies in Higher Education, 42(2), 315-330. https://doi.org/10.1080/03075079.2015.1045481

Simons, J., Beaumont, K., \& Holland, L. (2018). What factors promote student resilience on a level 1 distance learning module? Open Learning: The Journal of Open, Distance and e-Learning, 33(1), 4-17. http://dx.doi.org/10.1080/02680513.2017.1415140

Smith, D. W. (2006). Phenomenology. In L. Nadel (Ed.), Encyclopedia of cognitive science (pp. 1-7). Wiley \& Sons. https://doi.org/10.1002/0470018860.s00153

Smith, J. A., Flower, P., \& Larkin, M. (2009). Interpretative phenomenological analysis. SAGE.

Smith, K. J., Haight, T. D., Emerson, D. J., Mauldin, S., \& Wood, B. G. (2020). Resilience as a coping strategy for reducing departure intentions of accounting students. Accounting Education, 29(1), 77-108. http://dx.doi.org/10.1080/09639284.2019.1700140

Spady, W. G. (1970). Dropouts from higher education: An interdisciplinary review and synthesis. Interchange, 1(1), 64-85. https://doi.org/10.1007/BF02214313

Theron, L. C., \& Theron, A. M. C. (2014). Education services and resilience processes: resilient black South African student's experiences. Children and Youth Services Review, 47(3), 297-306. https://doi.org/10.1016/j.childyouth.2014.10.003

Tinto, V. (1975). Dropout from higher education: A theoretical synthesis of recent research. Review of Educational Research, 45(1), 89-125. https://doi.org/10.3102/00346543045001089

Vasconcellos, E. G. (2017). Stress, coping, burnout, resiliência: Troncos de uma mesma raiz. In: N. Silva Junior \& W. Zangari (Orgs.), A psicologia social e a questão do hifen (pp. 285-295). Blüncher. http://dx.doi.org/10.5151/9788580392357-20

Wilks, S. E., \& Spivey, C. A. (2010). Resilience in undergraduate social work students: Social support and adjustment to academic stress. Social Work Education, 29(3), 276-288.

https://doi.org/10.1080/02615470902912243 


\section{About the Authors}

\section{Samuel de Oliveira Durso}

Faculdade FIPECAFI

sodurso@gmail.com

ORCID: https://orcid.org/0000-0003-0016-3611

Samuel is a professor and researcher at Faculdade FIPECAFI. He holds a PhD in accounting from Universidade de São Paulo (USP/Brazil) and master's degree in accounting from Universidade Federal de Minas Gerais (UFMG/Brazil). He holds a bachelor's degree in economics also from UFMG.

\section{Luís Eduardo Afonso}

Universidade de São Paulo

lafonso@usp.br

ORCID: https://orcid.org/0000-0003-4639-8299

Luis is an associate professor at Universidade de São Paulo (USP/Brazil). He holds a PhD in economics from USP and a master's degree in economics from Fundação Getúlio Vargas (FGV/Brazil). He holds a bachelor's degree in economics and engineering both from USP. CNPq Research Productivity Scholarship - Level 2 (Brazil).

\section{Susan Beltman}

Curtin University

S.Beltman@curtin.edu.au

ORCID: https://orcid.org/0000-0003-0998-9962

Susan is an associate professor at Curtin University. She holds a PhD and master's in education from Murdoch University (Australia). Her teaching and research areas of interest include educator well-being and resilience, motivation, and school and community programs involving mentoring and role models. She has experience in qualitative research methodologies.

\section{About the Guest Editors}

\section{María Verónica Santelices}

Emailvsanteli@uc.cl

ORCID: https://orcid.org/0000-0003-4062-0047

Associate Professor of the Faculty of Education of the Catholic University of Chile. Her work has been published in specialized journals such as the Harvard Educational Review, Educational Psychological Measurement and Higher Education. Her interests combine measurement and educational policies, focusing on access and performance issues in higher education. Her research has been funded by the National Research and Development Agency of Chile, through Fondecyt and Milenio projects, and by the Ministry of Education through FONIDE projects. She is the author of the books The Quest for Equity in Chile's Higher Education: Decades of Continued Efforts (Lexington Books) and Equity in Higher Education. Design and Results of Access Programs in Selective Universities (Ediciones Universidad Católica de Chile and CEPPE UC). She received her Ph.D. in Education from the University of California Berkeley and a Master's in Public Policy from the same university. 


\section{Sergio Celis}

Universidad de Chile

Emailscelis@uchile.cl

Assistant professor at the School of Engineering and Sciences of the University of Chile. His research focuses on higher education, particularly on science and technology. His main lines of research are the experience of students in the first years of engineering and science, the teaching of mathematics in open access institutions, academic experience in graduate programs, academic work, and research policies. He is the vice president of the Chilean Society for Engineering Education (SOCHEDI). He is a civil industrial engineer from the University of Chile and a Ph.D. in higher education from the University of Michigan.

ORCID: https://orcid.org/0000-0002-0502-5608

\section{SPECIAL ISSUE \\ Student Experience in Latin American Higher Education education policy analysis archives}

Volume 29 Number $156 \quad$ November 22, 2021

ISSN 1068-2341

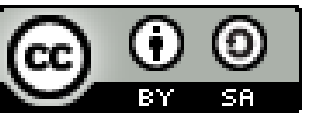

Readers are free to copy, display, distribute, and adapt this article, as long as the work is attributed to the author(s) and Education Policy Analysis

Archives, the changes are identified, and the same license applies to the derivative work. More details of this Creative Commons license are available at https://creativecommons.org/licenses/by-sa/4.0/. EPAA is published by the Mary Lou Fulton Teachers College at Arizona State University. Articles are indexed in CIRC (Clasificación Integrada de Revistas Científicas, Spain), DIALNET (Spain), Directory of Open Access Journals, EBSCO Education Research Complete, ERIC, Education Full Text (H.W. Wilson), QUALIS A1 (Brazil), SCImago Journal Rank, SCOPUS, SOCOLAR (China).

About the Editorial Team: https://epaa.asu.edu/ojs/index.php/epaa/about/editorialTeam Please send errata notes to Audrey Amrein-Beardsley at audrey.beardsley@asu.edu

Join EPAA's Facebook community at https://www.facebook.com/EPAAAAPE and Twitter feed@epaa_aape. 